\title{
Spatial and temporal dynamics of irrigation water quality under drought conditions in a large reservoir in Southern Portugal
}

\author{
Alexandra Tomaz (D) Patrícia Palma • Sofia Fialho • \\ Ana Lima • Paula Alvarenga • Miguel Potes • \\ Rui Salgado
}

Received: 26 July 2019/Accepted: 19 December 2019 / Published online: 6 January 2020

(C) Springer Nature Switzerland AG 2020

\begin{abstract}
Water is a scarce resource in the Mediterranean region where adverse climatic conditions promoting water shortages tend to increase with climate change. Under water scarcity conditions and high atmosphere evaporative demand, the risks of decreased water quality, and land salinization are major threats to the sustainability of irrigated agriculture in this region. The assessment of the quality of irrigation water is increasingly important to ensure the maintenance of long-term salt balance at a crop, farm, and regional scale. This study is focused on the spatial and temporal variability
\end{abstract}

Electronic supplementary material The online version of this article (https://doi.org/10.1007/s10661-019-8048-1) contains supplementary material, which is available to authorized users.

A. Tomaz $\cdot$ P. Palma $\cdot$ S. Fialho $\cdot$ A. Lima

Escola Superior Agrária, Instituto Politécnico de Beja, R. Pedro

Soares S/N, 7800-295 Beja, Portugal

A. Tomaz $(\bowtie)$

GeoBioTec, Universidade Nova de Lisboa. Campus da Caparica, 2829-516 Caparica, Portugal

e-mail: atomaz@ipbeja.pt

P. Palma $\cdot$ M. Potes $\cdot$ R. Salgado

Instituto de Ciências da Terra (ICT), Universidade de Évora,

Évora, Portugal

P. Alvarenga

LEAF - Centro de Investigação em Agronomia, Alimentos,

Ambiente e Paisagem, Instituto Superior de Agronomia,

Universidade de Lisboa, Lisbon, Portugal

R. Salgado

Escola de Ciências e Tecnologia, Universidade de Évora, Évora, Portugal of water quality for irrigation in the Alqueva reservoir (Southern Portugal). The assessment was performed every 2 months during a distinctive drought year (2017) and included inorganic ions $\left(\mathrm{Na}^{+}, \mathrm{Ca}^{2+}, \mathrm{Mg}^{2+}\right.$, $\mathrm{K}^{+}, \mathrm{NH}_{4}{ }^{+}, \mathrm{Cl}^{-}, \mathrm{F}^{-}, \mathrm{SO}_{4}{ }^{2-}, \mathrm{NO}_{3}{ }^{-}$, and $\left.\mathrm{NO}_{2}{ }^{-}\right), \mathrm{pH}$, and electric conductivity $\left(\mathrm{EC}_{\mathrm{W}}\right)$ of water. Sodium adsorption ratio (SAR) was calculated, and potential soil permeability problems were estimated. The assessment showed significantly higher values of the physicochemical parameters in the most upstream sites, located near tributaries inflows, and an upward trend in ion concentrations throughout the year, with significantly higher concentrations of $\mathrm{Na}^{+}, \mathrm{Mg}^{2+}, \mathrm{Cl}^{-}$, and $\mathrm{SO}_{4}{ }^{2}$, registered through May to November, reflecting the severe drought felt in the summer, autumn, and winter. The evaluation of water quality for irrigation indicated a slight to moderate risk of reduced infiltration rates, which should be considered whenever sprinkler irrigation is used, mainly in fine-textured soils, which are prevalent in the irrigated area. The multivariate statistical approach, using principal component analysis and factor analysis, identified two principal components related to salinity and nutrient concentrations. The cluster analysis revealed three groups of similarity between samples pointing to a more time- than space-controlled pattern. Overall, the temporal dynamics of the water physicochemical parameters could indicate that an abnormal annual distribution of precipitation and temperature may distort seasonal differences. To prevent water and soil degradation, a more frequent assessment of the water quality should be considered, allowing for the selection of appropriate soil and water management measures in irrigated areas. 
Keywords Irrigation areas · Water salinity - SAR . Drought $\cdot$ Water quality assessment

\section{Introduction}

Pronounced seasonal and interannual variability in the distribution of precipitation is a trait of the Mediterranean climate. This variability can lead to long drought periods whose severity has increased in the past decades because of greater atmospheric evaporative demand resulting from temperature rise caused by climate change (EEA 2012; IPCC 2014; Vicente-Serrano et al. 2014). Increased climatic aridity is leading to higher crop water requirements, making agriculture in many Mediterranean regions more dependent on irrigation networks to counteract low water availability. However, the expansion of irrigation is usually accompanied by agricultural intensification and large-scale changes in land use, which are likely to increase soil degradation processes (EC 2000; Valverde et al. 2015). The reduction in water quantity and quality and the development of soil salinization induce deleterious and often irreparable impacts on crop production and soil quality, increasing the risk of desertification (Iglesias et al. 2018; Williams 1999; Zalidis et al. 2002). Scanlon et al. (2007) refer that we are far from understanding the full impact of land use changes in many areas, since there are long time lags between land use changes and system response. However, as stated by Hillel (2000), when referring to the processes of degradation that have threatened the sustainability of irrigated agriculture since its beginning in the Fertile Crescent, "the (salinization) problem is age-old" and "continue to plague irrigation districts today no less than in the past". Several recent studies focusing on the evaluation of drought impacts on the degradation of water quality in rivers, lakes, and reservoirs (e.g., Mosley et al. 2012; Mosley 2015; van Vliet and Zwolsman, 2008), or on water and soil salinity (e.g., Etteieb et al. 2017; Gkiougkis et al. 2015; Hu et al. 2019; Jones and van Vliet 2018; Merchán et al. 2013), have exposed a global growing trend in regions with water limitations and under climatic uncertainty conditions.

In semiarid or Mediterranean-type climate regions, as the Southern Portugal region of Alentejo, traditional rainfed agriculture, conditioned by water availability constraints, has been gradually replaced by irrigated agriculture, whenever private or public investments have been made in the establishment of irrigation projects. In recent years, with the irrigation network of the Alqueva Multi-Purpose Development Project (EFMA Emprendimanto de Fins Múltiplos de Alqueva), farmers in Alentejo are more and more resorting to the irrigation of their crops, and the region is witnessing a profound transformation of the agricultural landscape and of the farming systems (Tomaz et al. 2018; Valverde et al. 2015). This large irrigation scheme started to operate in 2002 and presently covers nearly 120,000 ha (EDIA 2017). The growing demand for irrigation water in the region has been inevitably accompanied by an increase in the use of additional inputs, like mineral fertilizers and pesticides, which can be a cause of resource degradation when unsuitable agronomic practices are used, threatening the agroecosystems sustainability in the medium to long term (Paranychianakis and Chartzoulakis 2005; Valverde et al. 2015; Zalidis et al. 2002).

The EFMA is centered on the Alqueva reservoir, the largest artificial lake in the Iberian Peninsula, which provides water for public supply, irrigation, industry uses, energy production, and tourism. In fact, it constitutes the most important water supply source in Southern Portugal, so its sustainability is essential to meet the problems of water scarcity in this region. Studies carried out in this reservoir during its filling period, by Serafim et al. (2006), report a spatial and temporal heterogeneity of water quality, determined by stratification/mixture processes, inorganic (mineral) content, and oxygenation. Based on the total phosphorus and chlorophyll content in its early years, Morais et al. (2007) classified the Alqueva reservoir as an eutrophic system. Palma et al. (2010, 2014a, 2014b, 2015) found results that showed a heavily modified water body, with ecotoxicological risk to aquatic organisms induced mainly by pesticide and metal pollution. Furthermore, the results highlighted an increment over time of organic matter and nutrients in the water body and of trace elements in the sediments. The results from these studies, although very important as an alert for the need to a continuous assessment of the chemical and ecological status of the system, did not focus on the water quality for irrigation and did not account for the possible restrictions in its use when considering agricultural productivity and impacts on soil properties, namely, soil structure deterioration resulting from an excess of sodium $\left(\mathrm{Na}^{+}\right)$in the soil. The knowledge of water chemical composition, and of its spatial and temporal trends, is required to (i) evaluate water suitability for irrigation; 
(ii) define the appropriate criteria for water quality evaluation; (iii) outline tools for water and soils management; and (iv) implement appropriate irrigation and drainage practices (Beltrán 1999; Hillel 2000; Lutz et al. 2016; Machado and Serralheiro 2017; Paranychianakis and Chartzoulakis 2005; Zalidis et al. 2002). All these endpoints are useful to increase the environmental sustainability of agricultural soils and of surface and groundwater, in irrigated lands of the Mediterranean basin.

Taking the above into consideration, this study aimed to contribute to the implementation of sustainable resources management strategies in regions affected by water scarcity. For this purpose, the objectives of this study were (i) to assess the Alqueva reservoir water quality for irrigation; (ii) to understand spatial and/or temporal patterns in a drought year using multivariate statistical analyses; (iii) to support the design of strategies for an effective sampling and assessment of water quality for irrigation; and (iv) to indicate water resources and agricultural water management adaptations to cope with salinization processes in the Mediterranean region when intensive agricultural practices supported by irrigation are used.

\section{Materials and methods}

Study area

The study area is the Alqueva reservoir, located along the main course of the Guadiana River, in the Portuguese southern region of Alentejo (Fig. 1). The lithology of the Guadiana Basin is dominated by greywacke, schist, and a volcano-sedimentary complex with polymetallic sulfide complexes of $\mathrm{Cu}, \mathrm{Pb}$, and $\mathrm{Fe}-\mathrm{Mn}$ and carbonate rocks (MilHomens et al. 2007). The reservoir, with a total storage capacity of $4150 \mathrm{hm}^{3}$, is the center of the EFMA, providing water for public supply, irrigation, industry uses, energy production, and tourism. The global irrigation plan benefits a total area of 120,000 ha, of which about 70,000 ha were in operation in 2017 with a total water supply of over $245 \mathrm{hm}^{3}$ per year (EDIA 2017). Predominant soils in the irrigation area are Luvisols (orthic, calcic, vertic, and gleyic), Vertisols (chromic and pelic), and Cambisols (calcic and chromic) where the main parent materials are intermediate or basic igneous rocks (diorite and gabbro), limestone, and schist (GPAa 2005; IUSS Working Group WRB 2014). According to EDIA (2017), the main crops grown in the area during 2017 were olive (Olea europaea L.), occupying more than half of the irrigated area (56\% in 2017); maize (Zea mays L.), the second most important crop, occupying $10 \%$ of the area; grapevine (Vitis vinifera L.) in $7 \%$ of the area; almond (Prunus dulcis (Mill.) D. A. Webb), in $5 \%$ of the area; forage crops in $5 \%$ of the area; wheat (Triticum aestivum L. and Triticum durum Desf.), and barley (Hordeum vulgare L.), in 3\% of the area. The remaining area is mainly occupied by open-field horticultural crops, like melon (Cucumis melo L.) and tomato (Solanum lycopersicum L.).

Climate conditions and meteorological data

The meteorological data used in this study were recorded in seven automatic weather stations, belonging to IPMA, the Portuguese Institute for Sea and Atmosphere (Beja and Évora); to SAGRA, the Agro-meteorological network support service to farmers in the Alentejo region (Beja) (COTR 2017); and to ICT, Earth Sciences Institute (Mitra, Portel, Barbosa and Cid Almeida) (ICT 2019). The latter two (Barbosa and Cid Almeida) are installed close to the Alqueva reservoir, in order to characterize the climate near the reservoir and the impact of the water mass on the atmosphere (some results using data from these stations can be found in Potes et al. 2017 and Iakunin et al. 2018). The locations of the stations are indicated in Fig. 1.

In the region, climate is predominantly Mediterranean, or temperate with hot and dry summer (Csa, in Köppen classification), with a small area of midlatitude steppe (Bsk, in Köppen classification). According to IPMA (2018), the 1981-2010 climatological normal for annual rainfall, in the two main towns in the area, Beja and Évora (stations No 562 and No 588 of the Portuguese synoptic network), is 558 and $585 \mathrm{~mm}$, respectively (Table 1), and for average temperature is $16.9^{\circ} \mathrm{C}$ in Beja and $16.5^{\circ} \mathrm{C}$ in Évora. The year 2017, in Portugal, was classified as extremely hot and dry, being the third-driest and the second-warmest year since routine observations were established in 1931. The period from April to December, with persistently negative precipitation anomalies (except August, in the region under study), was the driest of the last 87 years IPMA 


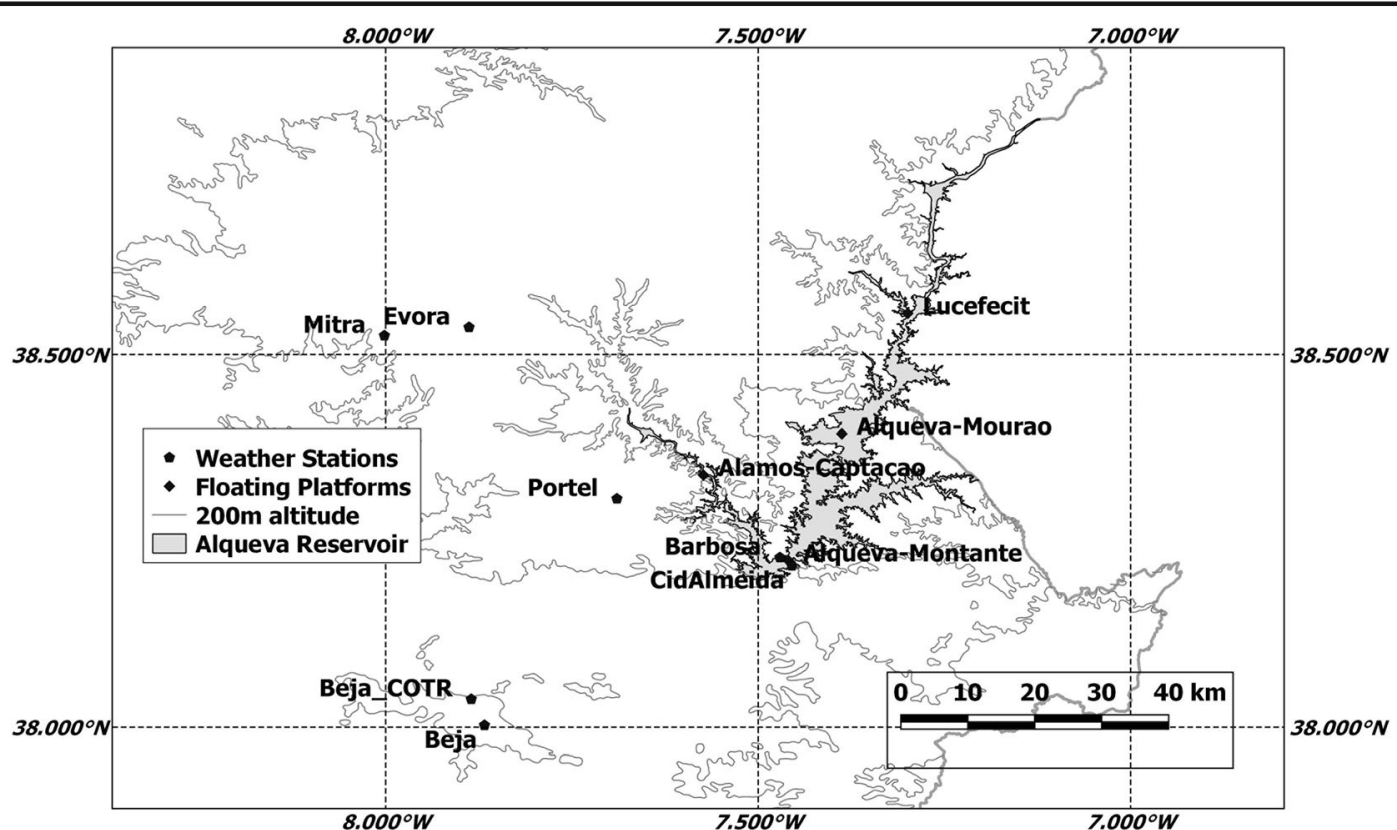

Fig. 1 Map showing the location of the Alqueva irrigation area, the sampling sites in floating platforms at the Alqueva reservoir (Alamos-Captação (Al), Alqueva-Montante (Mn), Alqueva-
Mourão (Mr), and Lucefécit (Lf)), and the automatic weather stations (Beja, Beja-COTR, Évora, Mitra, Portel, Barbosa, and Cid Almeida)
(2017). Daily precipitation registered at the automatic weather station in Beja (COTR) is presented in Fig. S1.

On the basis of data, in Table 1, and on the information of the National Climatological Bulletin (IPMA 2017), the main characteristics of the weather in the EFMA area during 2017 were the: (i) from January to March, the values of precipitation and temperature were close to the climatological normal; (ii) from April to December, the precipitation was below the normal, particularly in April, June, July, September, and October; (iii) in April and May, temperatures were higher than the normal; and (iv) in June and October, temperatures were exceptionally high, with several heat waves and temperature records. These long periods of high temperatures and low precipitation gave rise to increased aridity, so that by the end of October the whole EFMA area was under extreme drought, the severest class according to the PDSI index (Palmer drought severity Index; Palmer 1965).

Sampling and water physicochemical analyses

Four sampling sites in floating platforms were established at the Alqueva reservoir (Fig. 1): ÁlamosCaptação (Al; 38 20'30.00"N, 7³4'40.00"W), Alqueva-Montante (Mn; 38 $\left.12^{\prime} 55^{\prime \prime} \mathrm{N}, 7^{\circ} 29^{\prime} 28^{\prime \prime} \mathrm{W}\right)$,
Alqueva-Mourão (Mr; 38 $23^{\prime} 60.00^{\prime \prime} \mathrm{N}, 7^{\circ} 23^{\prime} 25.80^{\prime \prime} \mathrm{W}$ ), and Lucefécit (Lf; 38 $\left.33^{\prime} 6.32^{\prime \prime} \mathrm{N}, 7^{\circ} 17^{\prime} 52.86^{\prime \prime} \mathrm{W}\right)$. The $\mathrm{Al}$ site was chosen because it is near the Álamos pumping station, an inlet where water is elevated to the conveyance network of the Alqueva subsystem, one of the three irrigation subsystems in the plan. The $\mathrm{Mn}$ site was selected to ensure representativeness of the reservoir area. $\mathrm{Mr}$ and Lf sites were chosen considering previous results for the reservoir water quality assessment, which indicated these sites among those with worst water quality (Morais et al. 2007; Palma et al. 2010, 2014a; Serafim et al. 2006).

The study comprised six sampling campaigns during 2017, performed in January (Jan), March (Mar), May, July (Jul), September (Sept), and November (Nov) (Fig. S1). The months of Jan, Mar, and Nov are included in the wet season, and the dry season includes May, Jul, and Sept, according to the Portuguese Environment Agency (APA - Agência Portuguesa de Ambiente), for the Alentejo region. This hydrological permanence classification (permanent or intermittent streams) takes into account the importance of the variability of the tributary's hydrological regimes for water quality, especially in the southern regions of Portugal, reflecting the regional expression of the Mediterranean climate, which is 
Table 1 1981-2010 Climatological normal for Beja and Évora synoptic stations (Portuguese network from IPMA) and meteorological data from 2017, registered in automatic weather stations located in the region

\begin{tabular}{|c|c|c|c|c|c|c|c|c|c|}
\hline & \multicolumn{2}{|c|}{ 1981-2010 Climatological normal } & \multicolumn{7}{|c|}{2017 Meteorological data } \\
\hline & Beja & Évora & Beja (IPMA) & Beja (COTR) & Évora (IPMA) & Mitra & Portel & Barbosa & Cid Almeida \\
\hline & \multicolumn{9}{|c|}{ a) Monthly and annual mean temperatures $\left({ }^{\circ} \mathrm{C}\right)$} \\
\hline Jan & 9.7 & 9.6 & 8.7 & 8.9 & 8.2 & 8.3 & 8.0 & - & - \\
\hline Feb & 10.8 & 10.7 & 11.2 & 11.6 & 11.0 & 11.0 & 10.6 & - & 11.4 \\
\hline Mar & 13.4 & 13.3 & 12.7 & 12.9 & 12.2 & 12.2 & 12.1 & 12.7 & 12.4 \\
\hline Apr & 14.6 & 14.3 & 16.9 & 16.8 & 16.5 & 16.6 & 16.7 & 17.3 & 16.6 \\
\hline May & 17.7 & 17.1 & 19.6 & 19.8 & 19.4 & 19.2 & 19.7 & 20.5 & 20.0 \\
\hline Jun & 22.0 & 21.4 & 24.0 & 24.3 & 24.0 & 24.0 & 24.8 & 25.4 & 25.2 \\
\hline Jul & 24.6 & 23.9 & 24.3 & 24.4 & 24.5 & 24.3 & 25.3 & 25.8 & 25.5 \\
\hline Aug & 24.8 & 24.1 & 24.6 & 24.6 & 24.8 & 24.6 & 25.5 & 26.0 & 25.6 \\
\hline Sept & 22.4 & 21.9 & 21.4 & 21.7 & 21.7 & 21.7 & 22.4 & 22.7 & 22.4 \\
\hline Oct & 18.2 & 17.7 & 21.5 & 21.5 & 20.8 & 20.8 & 20.7 & 21.5 & 20.4 \\
\hline Nov & 13.6 & 13.4 & 14.2 & 14.3 & 13.2 & 13.1 & 12.9 & 14.1 & 13.4 \\
\hline Dec & 10.7 & 10.5 & 10.0 & 10.1 & 9.3 & 9.2 & 9.0 & 10.0 & 9.3 \\
\hline \multirow[t]{2}{*}{ Year } & 16.9 & 16.5 & 17.5 & 17.6 & 17.2 & 17.1 & 17.4 & - & - \\
\hline & \multicolumn{9}{|c|}{ b) Monthly and annual accumulated precipitation (mm) } \\
\hline Jan & 66 & 61 & 65 & 62 & 39 & 33 & 58 & - & - \\
\hline Feb & 55 & 52 & 58 & 45 & 50 & 43 & 64 & - & - \\
\hline Mar & 41 & 44 & 84 & 79 & 78 & 71 & 89 & - & 51 \\
\hline Apr & 59 & 55 & 5 & 7 & 1 & 5 & 3 & - & 8 \\
\hline May & 43 & 47 & 17 & 20 & 44 & 44 & 23 & - & 23 \\
\hline Jun & 13 & 17 & 3 & 5 & 8 & 5 & 4 & - & 2 \\
\hline Jul & 2 & 4 & 0 & 0 & 0 & 0 & 0 & - & 0 \\
\hline Aug & 4 & 8 & 22 & 9 & 17 & 8 & 5 & - & 0 \\
\hline Sep & 30 & 32 & 0 & 0 & 0 & 0 & 0 & - & 0 \\
\hline Oct & 72 & 84 & 18 & 22 & 21 & 19 & 14 & - & 33 \\
\hline Nov & 77 & 88 & 64 & 63 & 45 & 32 & 43 & - & 30 \\
\hline Dec & 98 & 95 & 40 & 52 & 45 & 54 & 60 & - & 48 \\
\hline Year & 558 & 585 & 376 & 363 & 348 & 312 & 363 & & \\
\hline
\end{tabular}

- no record available. (a) Monthly and annual mean temperatures $\left({ }^{\circ} \mathrm{C}\right)$; (b) monthly and annual accumulated precipitation (mm)

characterized by dry and hot summers and mild and wet winters with concentrated rains (ARH Alentejo 2011).

At each sampling location, $2 \mathrm{~L}$ of surface water were collected, at a depth of $50 \mathrm{~cm}$, using a Van Dorn bottle. The water samples were stored in polyethylene bottles and transported to the laboratory, in a cooler at $4{ }^{\circ} \mathrm{C}$, where they were conserved and stored, following the requisites for water conservation for each parameter (APHA 1998). The major inorganic ions, decisive in the evaluation of water quality for irrigation, were determined using the officially recommended methods of analysis (APHA 1998), namely, ionic chromatography: sodium $\left(\mathrm{Na}^{+}\right)$, calcium $\left(\mathrm{Ca}^{2+}\right)$, magnesium $\left(\mathrm{Mg}^{2+}\right)$, potassium $\left(\mathrm{K}^{+}\right)$, ammonium $\left(\mathrm{NH}_{4}{ }^{+}\right)$, nitrate $\left(\mathrm{NO}_{3}{ }^{-}\right)$, nitrite $\left(\mathrm{NO}_{2}{ }^{-}\right)$, chloride $\left(\mathrm{Cl}^{-}\right)$, fluoride $\left(\mathrm{F}^{-}\right)$, and sulfate $\left(\mathrm{SO}_{4}{ }^{2-}\right)$, all in $\mathrm{mg} \mathrm{L}^{-1}$. Water $\mathrm{pH}$ and water electrical conductivity ( $\mathrm{ECw} ; \mathrm{dS} \mathrm{cm}^{-1}$ ) were measured in situ at a $50-\mathrm{cm}$ depth using a multiparametric probe YSI 6820 MPS probe®.

To assess the potential impact of water on aggregates dispersion and soil structure due to an excess of sodium 
present on the soil-exchange complex (US Salinity Laboratory Staff 1954), the sodium adsorption ratio (SAR) was calculated using Eq. (1) (ions concentrations in meq $\mathrm{L}^{-1}$ ):

$$
S A R=\frac{\left[\mathrm{Na}^{+}\right]}{\sqrt{\frac{\left[\mathrm{Ca}^{2+}\right]+\left[\mathrm{Mg}^{2+}\right]}{2}}}
$$

\section{Assessment of water quality for irrigation}

The evaluation of water quality for irrigation was performed using both the Portuguese legislation (Law-Decree No 236/1998 1998; which establishes quality standards, criteria and objectives with the purpose of protecting the aquatic environment and improving water quality according to its main uses) and the Food and Agriculture Organization of the United Nations (FAO) guidelines (Ayers and Westcot 1985) (Tables 2 and 3).

The FAO guidelines are based in the quality standards reported by Ayers and Westcot (1985), considering a "potential problem" approach assessed by three degrees of restriction on uses: none, slight to moderate, and severe (Table 3 ). The potential irrigation problems addressed are as follows: (i) salinity, assessed from ECw; (ii) infiltration rate of water into the soil, assessed using ECw and SAR, together; (iii)

Table 2 Portuguese quality standards of water intended for irrigation (Decree-Law No 236/1998, 1998)

\begin{tabular}{llll}
\hline Parameter & Units & $\mathrm{MRV}^{1)}$ & $\mathrm{MPV}^{2}$ \\
\hline $\mathrm{pH}$ & & $6.5-8.4$ & $4.5-9.0$ \\
Electric conductivity $(\mathrm{ECw})^{3)}$ & $\mathrm{dS} \mathrm{m}^{-1}$ & 1 & - \\
Chloride $\left(\mathrm{Cl}^{-}\right)$ & $\mathrm{mg} \mathrm{L}^{-1}$ & 70 & - \\
Fluoride $\left(\mathrm{F}^{-}\right)$ & $\mathrm{mg} \mathrm{L}^{-1}$ & 1 & 15 \\
Nitrate $\left(\mathrm{NO}_{3}{ }^{-}\right)$ & $\mathrm{mg} \mathrm{L}^{-1}$ & 50 & - \\
Sulfate $\left(\mathrm{SO}_{4}{ }^{2-}\right)$ & $\mathrm{mg} \mathrm{L}^{-1}$ & 575 & \\
Sodium adsorption Ratio (SAR) & & & 8 \\
\hline
\end{tabular}

\footnotetext{
1) MRV, maximum recommended value (or interval)

${ }^{2)} \mathrm{MPV}$, maximum permissible value (or interval)

3) For ECw, there is a remark: "It depends heavily on the resistance of crops to salinity, as well as the irrigation method and soil texture"; however, no detailed criterion is established

4) In the case of SAR, the observation says: "It depends on the water salinity, the characteristics of the soil and the type of crop to be irrigated." Again, no detailed criterion is established
}

specific ion toxicity by $\mathrm{Na}^{+}, \mathrm{Cl}^{-}$, or boron (B) in sensitive crops; and (iv) miscellaneous effects on sensitive crops, regarding $\mathrm{NO}_{3}{ }^{-}$(an excess of nitrates can cause nutritional imbalances that influence yield or production quality) and bicarbonate $\left(\mathrm{HCO}_{3}{ }^{-}\right)$concentrations (an excess of bicarbonate can corrode irrigation equipment, increasing maintenance and repair costs) and $\mathrm{pH}$.

Ayers and Westcot (1985) systematized and updated work previously developed by the US Salinity Laboratory Staff (1954), Wilcox (1955), Maas and Hoffman (1977), Rhoades (1977), or Oster and Schroer (1979). It establishes general standards for the assessment of the water quality for agricultural purposes to be used as a management tool, particularly at farm level, considering the specific local conditions of use. The proposed guidelines emphasize the long-term influence of water quality on crop production, soil conditions, and farm management and are intended for a wide range of conditions encountered in irrigated agriculture. Their range of usability is defined by the following basic assumptions: (i) a restriction on use does not indicate that the water is unsuitable for use, it indicates that there may be a limitation in choice of crop, or special management may be needed to achieve full productivity; (ii) the soil texture ranges from sandy loam to clay loam with good internal drainage; (iii) the climate is semiarid to arid and rainfall is low; (iv) the soil drainage is good, with no uncontrolled shallow water table present within $2 \mathrm{~m}$ of the surface; (v) surface or sprinkler irrigation methods (infrequent irrigation) are used, with at least $15 \%$ of percolation of the applied water below the root zone (the guidelines are too restrictive for drip irrigation, more frequent and efficient); (vi) the water uptake pattern by the crops in each quarter of the soil profile is $40 \%-30 \%-20 \%-10 \%$, so salinity increases with depth and is greatest in the lower part of the root zone; and (vii) the division between the three degrees of restriction on use (none, slight to moderate, and severe) are gradual, and there is no clear-cut breaking point (Ayers and Westcot, 1985).

\section{Statistical analyses}

All statistical analyses were carried out with the software Statistica 7 (StatSoft, Inc. 2004). Mean and standard deviation of ion concentrations and SAR (three repetitions), and in situ measurements of $\mathrm{ECw}$ and $\mathrm{pH}$, were plotted using graphical tools. 
Table 3 FAO guidelines for interpretation of water quality for irrigation (adapted from Ayers and Westcot, 1985).

\begin{tabular}{|c|c|c|c|c|}
\hline \multirow[t]{2}{*}{ Potential irrigation problem } & \multirow[t]{2}{*}{ Units } & \multicolumn{3}{|c|}{ Degree of restriction on use } \\
\hline & & None ${ }^{1)}$ & Slight to moderate ${ }^{2)}$ & Severe ${ }^{3)}$ \\
\hline \multicolumn{5}{|l|}{ Salinity ${ }^{4)}$} \\
\hline $\mathrm{ECW}$ & $\mathrm{dS} \mathrm{m}^{-1}$ & $<0.7$ & $0.7-3.0$ & $>3.0$ \\
\hline \multicolumn{5}{|l|}{ Infiltration 5) 6) } \\
\hline SAR $0-3$ and ECw & $\mathrm{dS} \mathrm{m}^{-1}$ & $>0.7$ & $0.7-0.2$ & $<0.2$ \\
\hline SAR $3-6$ and $\mathrm{ECW}$ & & $>1.2$ & $1.2-0.3$ & $<0.3$ \\
\hline SAR 6 - 12and ECw & & $>1.9$ & $1.9-0.5$ & $<0.5$ \\
\hline SAR $12-20$ and ECw & & $>2.9$ & $2.9-1.3$ & $<1.3$ \\
\hline SAR $20-40$ and $\mathrm{ECw}$ & & $>5.0$ & $5.0-2.9$ & $<2.9$ \\
\hline \multicolumn{5}{|l|}{ Specific ion toxicity ${ }^{7)}$} \\
\hline \multicolumn{5}{|l|}{ Sodium $\left(\mathrm{Na}^{+}\right)$} \\
\hline Surface irrigation & SAR & $<3$ & $3-9$ & $>9$ \\
\hline Sprinkler irrigation & $\mathrm{mg} \mathrm{L}^{-1}$ & $<69$ & $>69$ & - \\
\hline \multicolumn{5}{|l|}{ Chloride $\left(\mathrm{Cl}^{-}\right)$} \\
\hline Surface irrigation & $m g L^{-1}$ & $<142$ & $143-355$ & $>355$ \\
\hline Sprinkler irrigation & $\mathrm{mg} \mathrm{L}^{-1}$ & $<106$ & $>106$ & \\
\hline \multicolumn{5}{|l|}{ Miscellaneous effects ${ }^{8)}$} \\
\hline Nitrate $\left(\mathrm{NO}_{3}^{-}\right)$ & $\operatorname{mg~L}{ }^{-1}$ & $<5$ & $5-30$ & $>30$ \\
\hline $\mathrm{pH}$ & - & \multicolumn{3}{|c|}{ Normal range: $6.5-8.4$} \\
\hline
\end{tabular}

\footnotetext{
1) None - no soil or cropping problems are experienced. ${ }^{2)}$ Slight to moderate - gradually increasing care in selection of crop and management alternatives is required if full yield potential is to be achieved. ${ }^{3)}$ Severe - there will be soil and cropping problems or reduced yields, but even with cropping management designed especially to cope with poor quality water, a high level of management skill is essential for acceptable production. ${ }^{4)}$ Affects crop water availability; ${ }^{5)}$ Affects infiltration rate of water into the soil. ${ }^{6}$ Evaluated using ECw and SAR together; ${ }^{7)}$ Affects sensitive crops; ${ }^{8)}$ Affects susceptible crops.
}

Multivariate statistical analyses, namely, factor analysis (FA), including principal components analysis (PCA) for factor extraction, and cluster analysis (CA), were performed after methodologies described in Simeonov et al. (2003) and Palma et al. (2010, 2014a). Factor analysis tests latent factors causing observed variables; PCA extracts these factors by reducing correlated observed variables; CA assembles objects or cases into groups called clusters based on characteristics they possess (Shrestha and Kazama, 2007; Simeonov et al. 2003). The application of these multivariate statistical methods supports the interpretation of complex datasets, allowing the identification of possible factors or sources that influence the status of the water systems and offering valuable tools for the management of water resources (Muangthong and Shrestha 2015; Shrestha and Kazama, 2007; Simeonov et al. 2003; Li et al. 2018).

To sort the relative importance of time and site on the water physicochemical parameters, a preliminary analysis was performed using repeated measures ANOVA with two factors (month and site). One-way ANOVA was performed in the case of $\mathrm{ECw}$ and $\mathrm{pH}$, given their single "in situ" measurements and the resulting degrees of freedom. Differences between means were compared using Tukey's test $(p<0.05)$.

FA and PCA were made on normalized data $(\log \mathrm{x}$; $\mathrm{x}=$ mean value) to avoid misclassification due to the wide differences in data dimensionality (Liu et al. 2003). The FA/PCA approach aimed to understand the data structure, to find the most meaningful parameters, and to reduce de number of variables into a small number of independent variables (principal components). The principal components were retained after applying the Scree test (Cattell 1966), considering principal components with eigenvalues $>1$ that accounted for a proportion of variance $>10 \%$. The factor loadings, representing the correlation between the factors and the variables, were classified as "strong," "moderate," and "weak," 
corresponding to absolute loading values of $>0.75$, $0.75-0.50$, and $0.50-0.30$, respectively (Liu et al. 2003).

Hierarchical agglomerative CA was performed with the factor scores of the two-component model to detect similarity groups between sites and/or dates that could indicate spatial and/or temporal patterns in the data. The resulting clusters should exhibit high within-cluster homogeneity and high between-clusters heterogeneity (Shrestha and Kazama, 2007; Muangthong and Shrestha, 2015). The distance between clusters was evaluated using the Ward's method (Ward 1963) for the amalgamation (linkage) rule. The Euclidean distance for similarity measures was used as linkage distance (dlink), expressed as the percentage of the range from the maximum to the minimum distance (dmax) in the data, dlink/dmax*100 (Muangthong and Shrestha 2015; Shrestha and Kazama, 2007; Simeonov et al. 2003). Statistically significant clusters were first identified in a tree diagram considering a Euclidean distance of dlink/ dmax $* 100<$ or $=$ to $60 \%$ (Muangthong and Shrestha 2015; Shrestha and Kazama, 2007) and then plotted in a two-dimensional plane defined by the two principle components model.

\section{Results and discussion}

\section{Water physicochemical assessment}

The temporal and spatial variability of the cation and anion concentrations was characterized by their mean and standard deviation, represented by columns and whiskers (Figs. 2 and 3). In general, the dominant ion in most samples was $\mathrm{Cl}^{-}$, followed by $\mathrm{SO}_{4}{ }^{2-}$ and $\mathrm{Na}^{+}$. The order of cation abundance was $\mathrm{Na}^{+}>\mathrm{Ca}^{2+}>$ $\mathrm{Mg}^{2+}>\mathrm{K}^{+}>\mathrm{NH}_{4}{ }^{+}$. Concerning the anion chemistry, the order of anion abundance was $\mathrm{Cl}^{-}>\mathrm{SO}_{4}{ }^{2-}>\mathrm{NO}_{3}{ }^{-}>$ $\mathrm{F}->\mathrm{NO}_{2}^{-}$.

The main water chemistry of the reservoir may reflect the geology of the area, and its weathering dynamics, as reported by Etteieb et al. (2017) that, in a study for the assessment of the suitability of surface water for irrigation in Northern Tunisia, found the main chemistry of the river system controlled by the dissolution of gypsum and halite. However, several studies have described the influence of farming, both in rainfed and irrigated agriculture, and its contribution for salt leaching through deep percolation and runoff, and of nutrient-rich discharges resulting from other human activities, e.g., in an 8 -year study to evaluate the impact of the introduction of irrigation in a hydrological basin in Spain, Merchán et al. (2013) reported an increase in the annual loads of salts, mainly $\mathrm{NO}_{3}{ }^{-}$; Chotpantarat and Boonkaewwan (2018) observed a duplication in $\mathrm{NO}_{3}{ }^{-}$loads in a basin in Thailand affected by agriculture intensification and land use change; on a study to evaluate the effects of recent agricultural practices on drainage water quantity and quality in arid basins in Northwest China, Hu et al. (2019) found that the quality of drainage water deteriorated mainly due to expansion of new farmlands; Yang et al. (2019) reported that the fast development of agriculture and urbanization in the Hai He basin, in the North China plain, has resulted in discharging nutrientrich wastewater into lakes and reservoirs, leading to eutrophication and water scarcity. Concentrations of $\mathrm{Na}^{+}, \mathrm{Mg}^{2+}, \mathrm{NH}_{4}^{+}, \mathrm{Cl}^{-}, \mathrm{SO}_{4}{ }^{2}, \mathrm{NO}_{3}{ }^{-}$, and $\mathrm{F}^{-}$were significantly higher $(p<0.05)$ in Lf (Figs. 2 and 3; Table S1). Overall, and in accordance with Morais et al. (2007) and Palma et al. (2010, 2014a), ion concentrations were higher in $\mathrm{Lf}$, followed by $\mathrm{Mr}$, the most upstream sites, both located near tributary inflows, near the border, and more permeable to the influence of the input flux from Spain. There was an upward trend in ions concentrations throughout the year, with significantly higher concentrations of $\mathrm{Na}^{+}, \mathrm{Mg}^{2+}, \mathrm{Cl}^{-}$, and $\mathrm{SO}_{4}{ }^{2-}$, registered through May to Nov (Figs. 2 and 3; Table S1). Except for $\mathrm{SO}_{4}{ }^{2-}, \mathrm{NO}_{3}{ }^{-}$, and $\mathrm{NO}_{2}{ }^{-}$, ion concentrations occurred in the samples collected in Nov were significantly higher, which may reflect the severe drought felt in the summer and begin of autumn months. Nitrate is present in nitrogen fertilizers, strongly applied in annual spring-summer and permanent irrigated crops, but also in annual autumn-winter rainfed crops. Thus, the higher concentrations found in the water for $\mathrm{NO}_{3}{ }^{-}$, during the wet period could be due to agricultural drainage and runoff. Although $\mathrm{K}^{+}$leaching losses are less frequent, due to its tendency to be retained in the structure of clay minerals, it is an important plant nutrient commonly present in mineral fertilizers (usually combined with phosphorus and nitrogen forms), which are applied during the sowing of autumnwinter crops or in post-harvest of olives and other fruit trees. An excessive fertilization or irrigation can explain the $\mathrm{K}^{+}$concentrations found in $\mathrm{Al}$ at Nov (Fig. 1).

While $\mathrm{ECW}$ is a measure of the total dissolved salts and their potential effect on the soil osmotic potential 

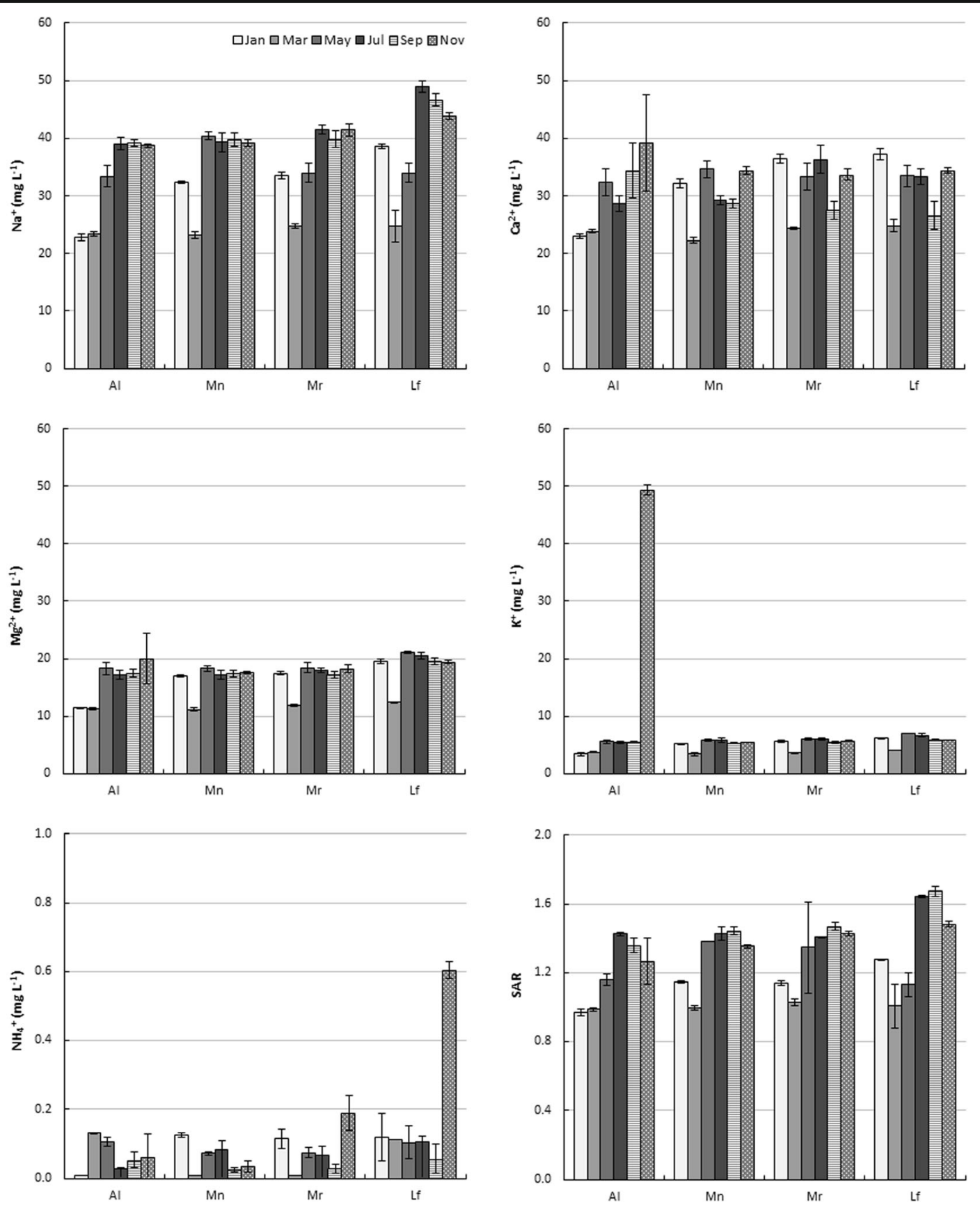

Fig. 2 Spatial and temporal variation of cations concentrations and SAR, during 2017, at the Alqueva reservoir. Bars represent the mean and whiskers represent the standard deviation for three

and on water stress in plants, SAR is related to the exchangeable sodium percentage, a soil property decisive in aggregate stability and soil permeability. Hence, SAR is considered an important indicator to predict the negative effects of $\mathrm{Na}^{+}$excess on soil physical properties (Ayers and Westcot 1985; Hanson 2006a; Rhoades

repetitions. Al, Álamos; Mn, Montante; Mr, Mourão; Lf, Lucefécit. Jan, January; Mar, March; Jul, July; Sept, September; Nov, November

et al. 1992; Tanji and Kielen 2002; U.S. Salinity Laboratory Staff 1954; Wilcox 1955). As expected, the patterns of temporal and spatial variation observed for $\mathrm{Na}^{+}$were also found for SAR (Fig. 2; Table S1). The same pattern can be observed for ECw (Fig. 4; Table S1), with spatial and temporal dynamics similar 

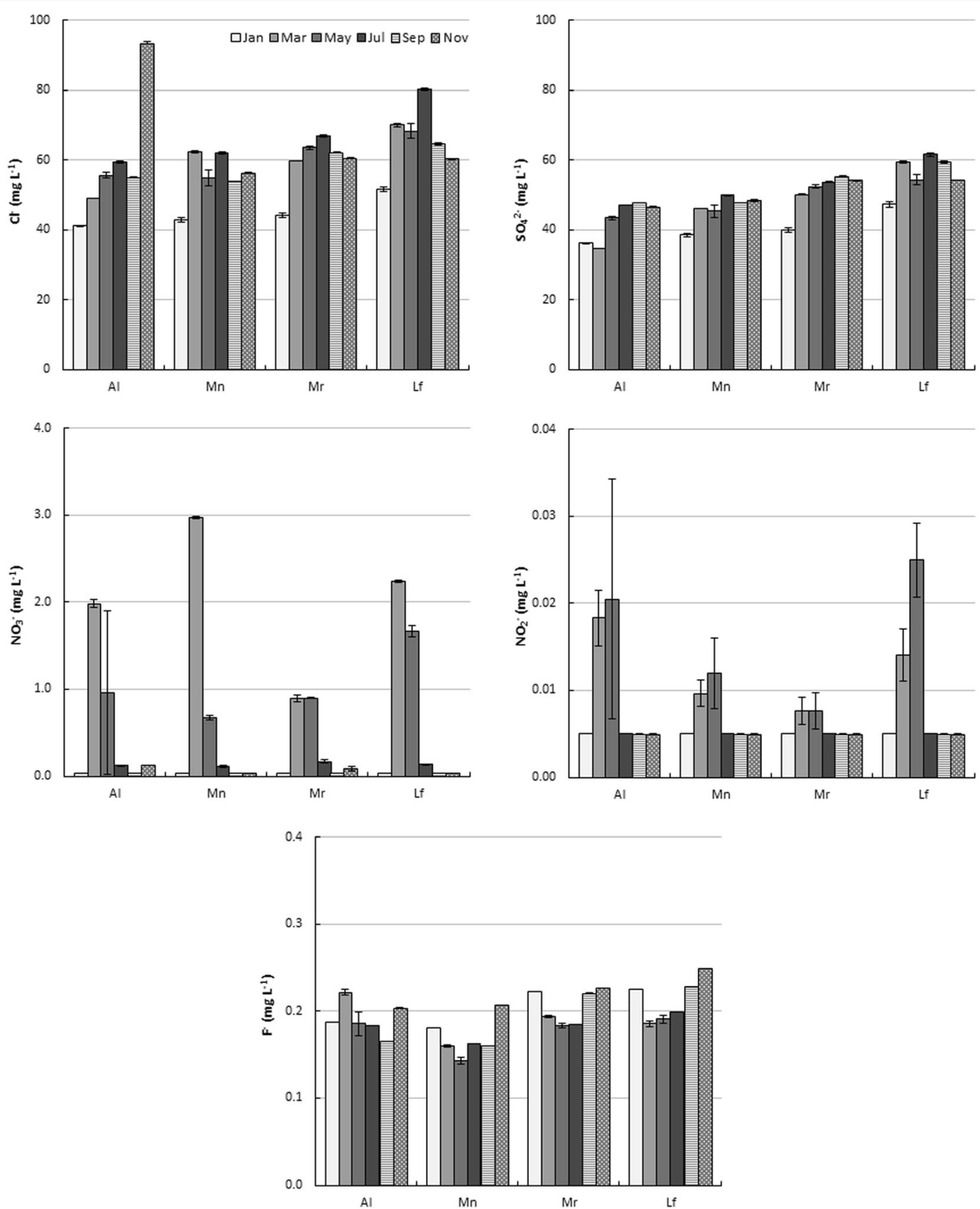

Fig. 3 Spatial and temporal variation of anions concentrations and SAR, during 2017, at the Alqueva reservoir. Bars represent the mean and whiskers represent the standard deviation for three

to $\mathrm{Na}^{+}$or $\mathrm{Cl}^{-}$, two of the most abundant ions in the Alqueva reservoir. Considering the Portuguese or the FAO standards, the maximum recommended values for $\mathrm{SAR}$ and $\mathrm{ECw}$ were never surpassed. The $\mathrm{pH}$ values increased from March to September, reaching an average value outside the allowed range (6.5 to 8.4$)$ in July. repetitions. Al, Álamos; Mn, Montante; Mr, Mourão; Lf, Lucefécit. Jan, January; Mar, March; Jul, July; Sept, September; Nov, November

Although with no statistically significant differences, the highest $\mathrm{pH}$ values occurred in the most upstream sites (Mr and Lf) (Fig. 4; Table S1); the maximum value (9.1) was registered at September in Lf (Fig. 4).

Overall, the temporal dynamics of the water physicochemical parameters during the year 2017 could 


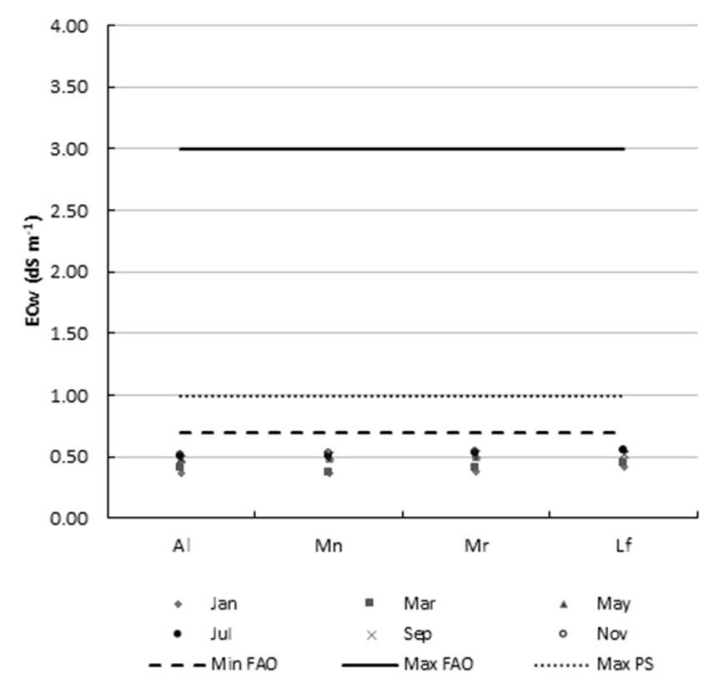

Fig. 4 Spatial and temporal variation of $\mathrm{ECw}$ and $\mathrm{pH}$, during 2017, at the Alqueva reservoir. Dots correspond to single in situ measurements. Full lines correspond to maximum recommended values from water quality standards. Dashed lines correspond to minimum recommended values from water quality standards. Max FAO and Min FAO, maximum and minimum recommended values from the FAO guidelines, respectively;

indicate that an abnormal annual distribution of precipitation and temperature may distort seasonal differences, and a more frequent assessment of the water quality should be considered.

Table 4 Parameters and potential risks found in noncompliance or with some degree of restriction on use, at the four sites during the six campaigns of the study, according to the Portuguese

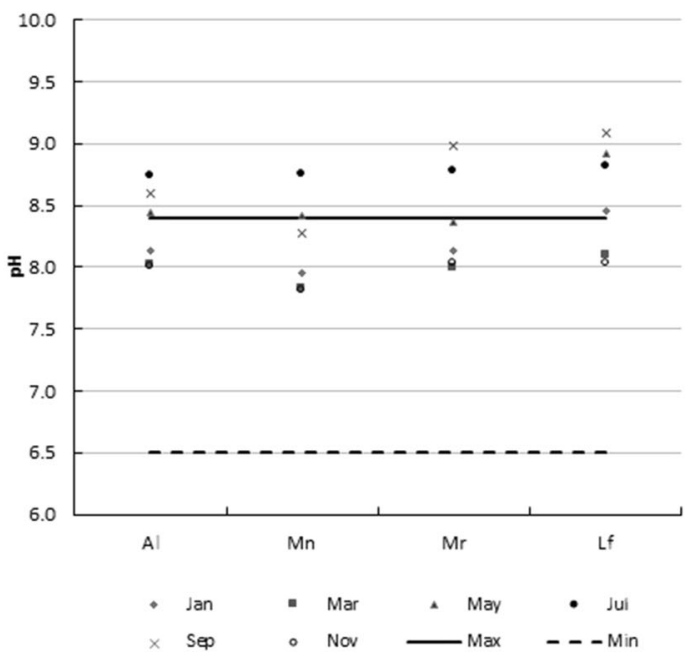

Max PS, maximum recommended value from the Portuguese standards; Min, minimum recommended value both from the FAO guidelines and from the Portuguese standards; Max, maximum recommended value both from the FAO guidelines and from the Portuguese standards. Al, Álamos; Mn, Montante; Mr, Mourão; Lf, Lucefécit. Jan, January; Mar, March; Jul, July; Sept, September; Nov, November

\section{Assessment of water quality for irrigation}

Table 4 summarizes the potential risks obtained for the ions analyzed, identifying the parameters in noncompliance or

legislation (Law-Decree No 236/1998, 1998) and the FAO guidelines (Ayers and Westcot, 1985)

\begin{tabular}{|c|c|c|c|c|c|c|c|c|c|c|c|c|c|}
\hline \multirow[t]{2}{*}{ Parameter/potential problem } & \multirow[t]{2}{*}{ Site } & \multicolumn{6}{|c|}{ Portuguese legislation } & \multicolumn{6}{|c|}{ FAO guidelines } \\
\hline & & Jan & Mar & May & Jul & Sep & Nov & Jan & Mar & May & Jul & Sep & Nov \\
\hline \multirow[t]{4}{*}{ Chloride } & $\mathrm{Al}$ & & & & & & $\mathrm{NC}$ & & & & & & \\
\hline & Mn & & & & & & & & & & & & \\
\hline & $\mathrm{Mr}$ & & & & & & & & & & & & \\
\hline & Lf & & $\mathrm{NC}$ & & $\mathrm{NC}$ & $\mathrm{NC}$ & & & & & & & \\
\hline \multirow[t]{4}{*}{$\mathrm{pH}$} & $\mathrm{Al}$ & & & $\mathrm{NC}$ & $\mathrm{NC}$ & $\mathrm{NC}$ & & & & $\mathrm{NC}$ & $\mathrm{NC}$ & $\mathrm{NC}$ & \\
\hline & $\mathrm{Mn}$ & & & $\mathrm{NC}$ & $\mathrm{NC}$ & & & & & $\mathrm{NC}$ & $\mathrm{NC}$ & & \\
\hline & $\mathrm{Mr}$ & & & & $\mathrm{NC}$ & $\mathrm{NC}$ & & & & & $\mathrm{NC}$ & $\mathrm{NC}$ & \\
\hline & Lf & $\mathrm{NC}$ & & $\mathrm{NC}$ & $\mathrm{NC}$ & $\mathrm{NC}$ & & $\mathrm{NC}$ & & $\mathrm{NC}$ & $\mathrm{NC}$ & $\mathrm{NC}$ & \\
\hline \multirow[t]{4}{*}{ Soil infiltration rate } & $\mathrm{Al}$ & - & - & - & - & - & - & SM & SM & SM & SM & SM & SM \\
\hline & $\mathrm{Mn}$ & - & - & - & - & - & - & SM & SM & SM & SM & SM & SM \\
\hline & $\mathrm{Mr}$ & - & - & - & - & - & - & SM & SM & SM & SM & SM & SM \\
\hline & Lf & - & - & - & - & - & - & SM & SM & SM & SM & SM & SM \\
\hline
\end{tabular}

Al, Álamos; Mn, Montante; Mr, Mourão; Lf, Lucefécit. NC, noncompliance; SM, slight to moderate degree of restriction - not classified in these standards 
with some degree of restriction on use, considering both the Portuguese legislation (Law-Decree No 236/1998 1998) and the FAO guidelines (Ayers and Westcot 1985). According to the Portuguese legislation, the only two parameters in noncompliance at some months and sites were $\mathrm{Cl}^{-}$and $\mathrm{pH}$. In the case of $\mathrm{Cl}^{-}$, it exceeded the maximum recommended value of $70 \mathrm{mg} \mathrm{L}^{-1}$ in $\mathrm{Al}$ (Nov) and Lf (Mar, Jul and Sep). As for $\mathrm{pH}$, in almost every site, from Jan to Sep, it exceeded 8.4, the upper limit of the allowed range. Considering the FAO standards, $\mathrm{Cl}^{-}$ concentrations would not constitute any degree of restriction, both for surface (with little relevance in the area) or sprinkler (most commonly used method in field crops) irrigation systems. When classified separately, in both the Portuguese and FAO recommended criteria, ECw and SAR values were not excessive. However, these parameters must be evaluated together to estimate possible soil infiltration rate decline and surface crust formation problems, because of the dispersing effect of an excess of sodium on the soil exchange complex (Hanson 2006a). This combined assessment showed a slight to moderate degree of restriction of use in all water samples analyzed. In fact, low-salt water can reduce infiltration even for a low SAR, that is, the effects of increasing sodium adsorption ratio grow as the salinity of the water decreases (Ayers and Westcot 1985; Compton 2011, Hanson 2006a; Rhoades et al. 1992). This outcome occurs when the salinity of the soil water or applied water is insufficient to counteract the negative effects of adsorbed sodium on soil structure.

Compton (2011) named it "the rainfall effect," referring that the leaching of salts from precipitation or excess irrigation water will reduce the salinity of the soil solution, while the reduction in SAR will be far smaller due to a buffer effect, performed by the exchangeable cations $\left(\mathrm{Ca}^{2+}, \mathrm{Mg}^{2+}, \mathrm{Na}^{+}\right.$, and $\left.\mathrm{K}^{+}\right)$, adsorbed in the soil matrix, on the ions dissolved in the soil solution. Therefore, leaching, as a result of a rainfall event or an irrigation, can cause infiltration reduction in the surface soil because the stabilizing effects of salinity on aggregate stability is lost when the $\mathrm{EC}$ of the water is reduced.

Soils most likely to show reduced infiltration and crusting are fine-textured soils, like those containing more than $30 \%$ expansive clay (smectite) in the profile or in some argic or natric subsurface horizons, as is the case of Luvissols and Vertissols, prevalent in the Alqueva irrigation area (GPAa 2005). Tanji and Kielen (2002) stated that at lower SAR levels, when chemical bonding is weakened, but no spontaneous dispersion takes place, inputs of energy are required for actual dispersion, and the use of sprinkler irrigation can increase the probability of surface crusting due to the physical disruption caused by the water drops as they impact the soil surface aggregates.

It should be noted that the institution responsible for the EFMA management uses the Portuguese legislation, not the FAO guidelines, to provide to irrigators biannual water quality bulletins with the results of monitoring performed in superficial water samples collected in January and May, near two of the water conveyance systems inlets (Álamos and Pedrógão). Hence, these bulletins do not include the joint evaluation of water EC and SAR to predict potential soil infiltration and permeability problems. These results and considerations highlight the need of introducing an assessment of potential infiltration problems caused by $\mathrm{Na}^{+}$and salinity together in the water quality for irrigation monitoring programs of the Alqueva reservoir. The potential soil salinization or sodification caused by irrigation with low-quality water depends not only on the water characteristics but also on other factors, such as soil texture, climatic conditions, soil drainage, irrigation method, and irrigation schedule. Therefore, early warning systems can contribute to the adoption of control measures and management changes required for long-term productivity (Bauder et al. 2014; Hillel 2000; Lutz et al. 2016; Machado and Serralheiro 2017; Paranychianakis and Chartzoulakis 2005).

\section{Multivariate statistical analysis}

Three principal components (PC1, PC2, and PC3) explained about $73.9 \%$ of the total variance (Table 5).

Following Liu et al. (2003) classification, PC1, which explained $44.6 \%$ of total variance, was strongly correlated with $\mathrm{Na}^{+}, \mathrm{Mg}^{2+}, \mathrm{SAR}$, and $\mathrm{ECw}$ and moderately correlated with $\mathrm{Ca}^{2+}, \mathrm{SO}_{4}{ }^{2-}, \mathrm{K}^{+}, \mathrm{pH}$, and $\mathrm{Cl}^{-}$; $\mathrm{PC} 2$ accounted for $17.0 \%$ of total variance and was mainly correlated with $\mathrm{NO}_{3}{ }^{-}$(strong correlation) but also $\mathrm{NO}_{2}{ }^{-}$ and $\mathrm{Cl}^{-}$; PC3 explained $12.3 \%$ of total variance and showed moderate participation of $\mathrm{NH}_{4}{ }^{+}$. Given the highest correlations obtained, PC1 was mainly a "salinity" component and PC2 a "nutrient" component. That is, PC1 denotes the influence of two of the most abundant cations in Alqueva water samples, $\mathrm{Na}^{+}$and $\mathrm{Mg}^{2+}$, and of the water salinity parameters, ECW and SAR. PC2 represents influences from nonpoint sources such as agricultural runoff, given its primary correlation with 
Table 5 Loadings of principal components (PC), eigenvalues, percentage of variance, and cumulative percentage of total variance for 13 water physicochemical parameters during 2017 at the Alqueva reservoir

\begin{tabular}{lrrr}
\hline & PC1 & PC2 & PC3 \\
\hline $\mathrm{Na}^{+}$ & $-\mathbf{0 . 9 6 0 0 9 6}$ & -0.135086 & -0.105107 \\
$\mathrm{NH}_{4}{ }^{+}$ & -0.467300 & -0.020882 & 0.669443 \\
$\mathrm{~K}^{+}$ & -0.575927 & 0.072992 & 0.400283 \\
$\mathrm{Ca}^{2+}$ & -0.718910 & -0.194439 & 0.487443 \\
$\mathrm{Mg}^{2+}$ & $-\mathbf{0 . 9 1 8 2 2 0}$ & -0.045624 & 0.185715 \\
$\mathrm{~F}^{-}$ & -0.259387 & -0.289497 & 0.346247 \\
$\mathrm{Cl}^{-}$ & -0.532594 & 0.673994 & -0.003300 \\
$\mathrm{NO}_{2}{ }^{-}$ & 0.412487 & 0.699674 & 0.382078 \\
$\mathrm{NO}_{3}{ }^{-}$ & 0.477753 & $\mathbf{0 . 8 2 0 0 2 0}$ & 0.214723 \\
$\mathrm{SO}_{4}{ }^{2-}$ & -0.636368 & 0.487257 & -0.302760 \\
$\mathrm{pH}^{-}$ & -0.543419 & 0.265721 & -0.442329 \\
$\mathrm{ECW}^{-}$ & $-\mathbf{0 . 8 3 9 0 2 1}$ & 0.365434 & -0.087922 \\
$\mathrm{SAR}^{-}$ & $-\mathbf{0 . 8 9 9 4 9 3}$ & -0.095039 & -0.316255 \\
Eigenvalue & 5.794446 & 2.214555 & 1.598573 \\
$\%$ total variance & 0.445727 & 0.170350 & 0.122967 \\
$\mathrm{Cumulative} \%$ variance & 5.794446 & 61.60770 & 73.90442 \\
\hline
\end{tabular}

Classification after Liu et al. (2003): bold values, strong correlation (absolute values $>0.75$ ); italic values, moderate correlation (absolute values in the range $0.75-0.50$ )

water-soluble nitrogen forms. Although in this assessment, $\mathrm{NH}_{4}{ }^{+}$was independent from other nitrogen forms, Simeonov et al. (2003) and Palma et al. (2014a) found correlation between $\mathrm{NO}_{3}{ }^{-}, \mathrm{NO}_{2}{ }^{-}$, and $\mathrm{NH}_{4}{ }^{+}$in their studies reporting, respectively, a monitoring program of surface waters in Northern Greece and the spatial and temporal variability of the water and sediments quality in the Alqueva reservoir. Contrary to the present study, where $\mathrm{Cl}^{-}$is in PC2, Liu et al. (2003) found strong correlation between $\mathrm{Cl}^{-}$, ECw, TDS (total dissolved salts), $\mathrm{Na}^{+}, \mathrm{K}^{+}, \mathrm{Mg}^{+}$, and $\mathrm{SO}_{4}{ }^{2-}$ in groundwater samples collected in a coastal area in Taiwan.

Cluster analysis gave three statistically significant groups from the 24 water samples collected during 2017 (Fig. S2; Fig. 5). The higher positive factor scores in PC1 were linked to season (Mar) and location (Al). Cluster 1 included all samples collected in Jan, except the ones from Lf. Cluster 2 grouped the largest number of samples, collected in Jul, Sept, and Nov, also including Lf samples collected in Jan (Lf/Jan). Due to the significantly higher concentrations found in Lf, when comparing with the other three sites, samples collected at this site during the wet season (Jan and Mar) were normally grouped with samples from other sites and driest months. Also, the drought levels felt during the autumn months are probably responsible for grouping the Nov samples along with samples collected during the typical dry season, in Jul and Sept. Cluster 3, with the higher positive scores in the "nutrient"-related principal component (PC2), groups water samples with higher $\mathrm{NO}_{3}{ }^{-}$and $\mathrm{NO}_{2}{ }^{-}$concentrations, collected in March (wet season) and May (dry season). Therefore, both clusters 2 and 3 grouped samples collected in all the sites but in different months, pointing to a homogeneity within clusters mainly due to the sampling date. This pattern indicates that the similarity between groups was more time-controlled than space-controlled, an important feature for the design of sampling strategies, especially in drought years.

Implications for monitoring programs and management adaptations

Taking the above into consideration, water quality monitoring and assessment programs in the Alqueva irrigation area should be long term and include not only sampling campaigns in January (winter) and May (spring) but also at the end of summer (September) and, when drought conditions set in, at the beginning of autumn (October), covering different periods in the wet and dry seasons. For an effective evaluation and mitigation of potential soil salinization processes (including soil sodicity), the combined evaluation of salinity and SAR in irrigation water should be introduced, following the FAO guidelines.

The effects of the reduction in osmotic and matric soil potential are additive, and soil salinity influences the range of available water for plants (Rengasamy 2010), thus influencing their water uptake and productivity. From a simple point of view, to achieve the salt balance in soil, the amount of salt coming in must be counterbalanced by the amount of salt being removed (Weil and Brady, 2016) in order to achieve a long-term "salt" sustainability of an irrigated field or an irrigation plan. Thereby, the monitoring and assessment of water quality for irrigation should be complemented with the recommendation of appropriate agricultural water management options for preventing those impacts, e.g., (i) leaching, the basic management tool for salinity control, refers to water that is purposely applied in excess to keep the salts in solution and transport them below the root zone; (ii) subsurface drainage systems to provide a 
Fig. 5 Scores of the water samples on the two-dimensional plane defined by the two principle components model. Each point corresponds to a sample, represented by the combination site/month. The ellipses delimit statistically significant clusters defined by an Euclidean distance of dlink/dmax $* 100<$ or $=$ to $60 \%$. Al, Álamos; Mn, Montante; Mr, Mourão; Lf, Lucefécit. Jan, January; Mar, March; Jul, July; Sept, September; Nov, November

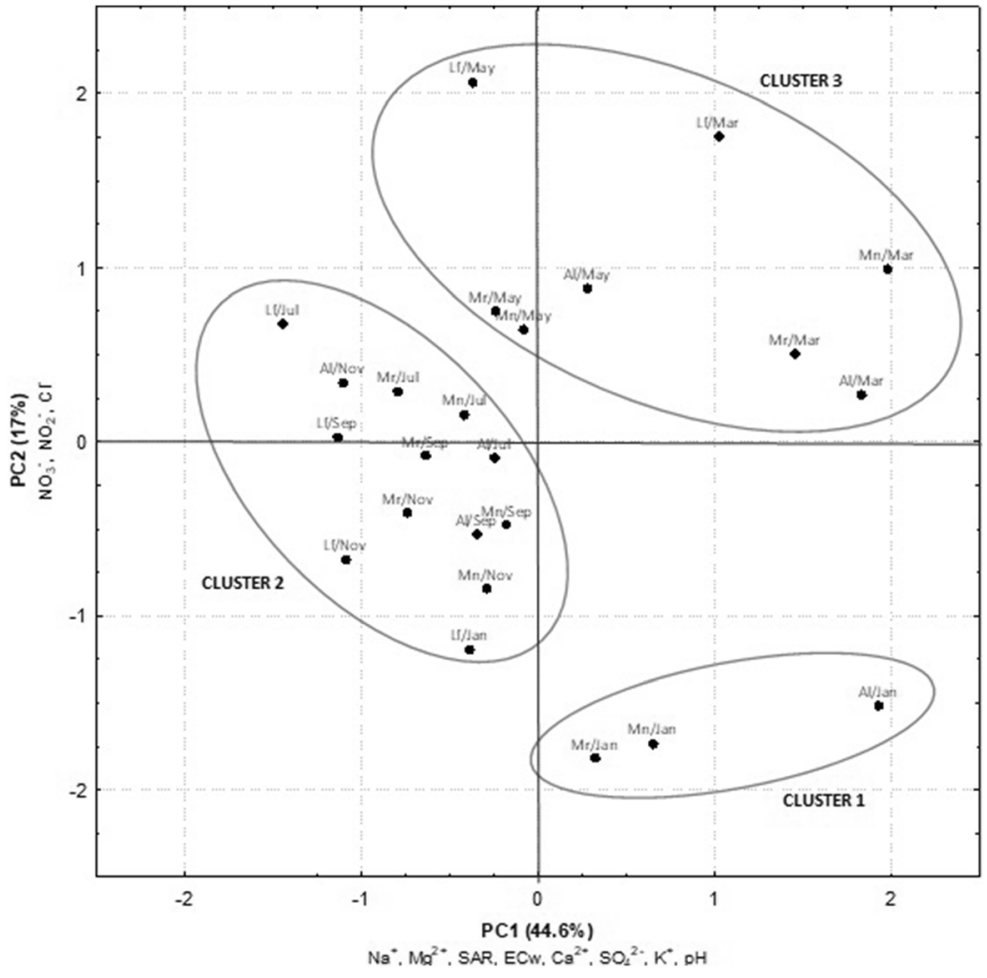

desirable root zone environment, by lessening the root zone waterlogging and improving salinity control by leaching; (iii) improved irrigation timing to help maintain more favorable moisture content in the soil, aiding the leaching process and avoiding ascending capillary flow from saline water tables; (iv) fertilizer management in order to avoid excessive nutrient application rates, a source of many soluble salts; (v) the use of more salt tolerant crops; (vi) the use of precision agriculture technologies, like variable rate irrigation (VRI) with saltsensing devices, to increase irrigation uniformity and efficiency; and (vii) the use of soil chemical amendments, like the application of gypsum $\left(\mathrm{CaSO}_{4} \cdot 2 \mathrm{H}_{2} \mathrm{O}\right)$, for sodicity control, to remove $\mathrm{Na}^{+}$ions from the exchange complex, replacing them with $\mathrm{Ca}^{2+}$ (Ayers and Westcot 1985; Hanson 2006b; Lutz et al. 2016; Machado and Serralheiro 2017; Tanji and Kielen 2002).

\section{Conclusions}

Physicochemical parameters showed significantly higher values in the most upstream sites, $\mathrm{Mr}$ and, especially, Lf. Agricultural runoff or leaching losses through irrigation return flows may be the cause for anomalous concentrations of salts, commonly present in $\mathrm{N}$ or $\mathrm{K}$ fertilizers formulations. There was an upward trend in ion concentrations throughout the year, with significantly higher concentrations of $\mathrm{Na}^{+}, \mathrm{Mg}^{2+}, \mathrm{Cl}^{-}$, and $\mathrm{SO}_{4}{ }^{2-}$, registered through May to Nov, which may reflect the severe drought felt in the summer and beginning of autumn months. Significantly higher $\mathrm{NO}_{3}{ }^{-}$concentrations were found in samples collected in March, a result that can be related to agricultural activities, namely, nitrogen fertilizations in the irrigation area.

The combined assessment of ECW and SAR showed a slight to moderate risk regarding soil infiltration rate decline and surface crust formation, in all water samples collected. These results should be considered whenever surface or sprinkler irrigation systems are used, particularly in fine-textured and poorly structured soils.

The multivariate approach with FA/PCA identified a "salinity"-related component, influencing $\mathrm{Na}^{+}, \mathrm{Mg}^{2+}$, $\mathrm{ECw}$, and SAR, and a "nutrient"-related component, highly correlated with $\mathrm{NO}_{3}{ }^{-}$and $\mathrm{NO}_{2}{ }^{-}$. The CA methodology revealed three groups of similarity between samples, denoting a more time-controlled than spacecontrolled pattern, which can be an important feature for the design of water sampling and assessment strategies in irrigation areas located in regions conditioned by 
seasonal and inter-annual climatic variability, especially under drought conditions.

Overall, these results could indicate that an abnormal annual distribution of precipitation and temperature may distort seasonal differences, and a more frequent assessment of the water quality should be considered.

The characteristics of the irrigation water can have a major role in the appearance or augmentation of soil secondary salinization and in the development of damaging effects of soil salinity on crops production, especially under climatic adverse conditions. In Mediterranean irrigation areas, water quality monitoring programs should be designed with sampling campaigns covering different wet and dry periods. In addition, the combined assessment of salinity and SAR should be introduced to evaluate potential infiltration problems, according to the FAO guidelines.

The assessment of water quality for irrigation should be complemented with guidance concerning the selection of appropriate management strategies for preventing those impacts. Further, it is also essential to conduct applied research, both in risk assessment studies and in ways to address the problems of soil and water degradation and resilience, especially under land use changes and climatic uncertainty.

Funding information This work was co-financed by the European Union through the European Regional Development Fund, under ALENTEJO 2020 (Alentejo Regional Operational Program) through the project "ALOP: Observation, forecasting and warning systems in the atmosphere and water reservoirs of the Alentejo" under the reference ALT20-03-0145-FEDER-000004.

This work is a contribution to the Projects UID/GEO/04035/ 2013 and UID/GEO/04683/2019, funded by FCT - Fundação para a Ciência e aTecnologia, Portugal.

\section{Compliance with ethical standards}

Conflict of interest On behalf of all authors, the corresponding author states that there is no conflict of interest.

\section{References}

ARH Alentejo (Administração da Região Hidrográfica do Alentejo - Administration of the Hydrographic Region of Alentejo). (2011). Plano de gestão das bacias hidrográficas integradas nas regiões hidrográficas 6 e 7: Região Hidrográfica 7. Lisboa: Administração da Região Hidrográfica do Alentejo I.P., Ministério do Ambiente e do Ordenamento do Território.

APHA (American Public Health Association). (1998). Standard methods for the examination of water and wastewater (twentieth ed.). Washington DC: American Public Health Association, American Water Works Association and Water Environmental Federation.

Ayers, R.S. \& Westcot, D.W. (1985). Water quality of agriculture. FAO irrigation and drainage paper no. 29, revision 1. Rome: Food and agriculture Organization of the United Nations.

Bauder, T.A., Waskom, R.M., Sutherland, P.L.\& Davis, J.G. (2014). Irrigation water quality criteria. Fact sheet no. 0.506 , crop series - Irrigation, Colorado State University extension. https://extension.colostate.edu/docs/pubs/crops/00506.pdf. Accessed 7 September 2018.

Beltrán, J. M. (1999). Irrigation with saline water: Benefits and environmental impact. Agricultural Water Management, 40, 183-194.

Cattell, R. B. (1966). The Scree test for the number of factors. Multivariate Behavioral Research, 1(2), 245-276. https://doi.org/10.1207/s15327906mbr0102_10.

Chotpantarat, S., \& Boonkaewwan, S. (2018). Impacts of land-use changes on watershed discharge and water quality in a large intensive agricultural area in Thailand. Hydrological Sciences Journal, 63(9), 1386-1407. https://doi.org/10.1080 /02626667.2018.1506128.

Compton, A. (2011). A review of rationale for EC and SAR standards. Montana Dept. of Environmental Quality.

COTR (Centro Operativo e de Tecnologia de Regadio - Irrigation Technology and Operation Center) (2017) SAGRA Sistema Agrometeorológico para a Gestão da Rega no Alentejo. http://www.cotr.pt/cotr/sagra.asp. Accessed 12 May 2018.

Decree-Law No 236/1998, 1 of August. On water quality assessment. Diário da República, $1^{\text {a }}$ SÉRIE-A Nº 176 - 1-8-1998.

EC (European Commission) (2000). The environmental impacts of irrigation in the European Union. A report to the Environment Directorate of the European Commission, $147 \mathrm{pp} \mathrm{http://ec.}$ europa.eu/environment/agriculture/pdf/irrigation.pdf. .

EDIA (Empresa de Desenvolvimento e Infraestruturas de Alqueva - Alqueva Development and Infrastructures Company) (2017). Anuário Agrícola de Alqueva 2017. Empresa de Desenvolvimento e Infraestruturas de Alqueva, S.A. http://www.edia.pt/pt/o-que-fazemos/apoio-aoagricultor/anuario-agricola/225. .

EEA (European Environment Agency) (2012). Climate change impacts and vulnerability in Europe 2012, 304 pp www. eea.europa.eu. Accessed 12 May 2018.

Etteieb, S., Cherif, S., \& Tarhouni, J. (2017). Hydrochemical assessment of water quality for irrigation: A case study of, the Medjerda River in Tunisia. Applied Water Sciences, 7, 469-480. https://doi.org/10.1007/s13201-015-0265-3.

GPAa (Grupo de Projecto Alqueva Agrícola - Alqueva Agricultural Project Group) (2005). Atlas Rural Zona de Intervenção de Alqueva. Tomo 5 in Plano de intervenção para a zona de Alqueva http://sir.dgadr.gov. pt/conteudos/gpaa/ Accessed 2 May 2018.

Gkiougkis, I., Kallioras, A., Pliakas, F., Pechtelidis, A., Diamantis, V., Diamantis, I., Ziogas, A., \& Dafnis, I. (2015). Assessment of soil salinization at the eastern Nestos River Delta, N.E. Greece. Catena, 128, 238-251. https://doi.org/10.1016/j. catena.2014.06.024.

Hanson, B.R. (2006a). How water quality affects infiltration. In: Hanson, B.R., Grattan, S.R. \& Fulton, A. (Eds.), Agricultural salinity and drainage (pp 47-50). University of California, 
Davis: Division of agriculture and natural resources publication 3375, University of California Irrigation Program.

Hanson, B.R. (2006b). Leaching fractions and irrigation uniformity. In: Hanson, B.R., Grattan, S.R. \& Fulton, A. (Eds.), Agricultural salinity and drainage (pp 131-132). University of California, Davis: Division of agriculture and natural resources publication 3375, University of California Irrigation Program.

Hillel, D. (2000). Salinity Management for Sustainable Irrigation. Integrating science, environment, and economics. Environmentally and socially sustainable development. Washington DC: The World Bank.

Hu, Q., Yang, Y., Han, S., \& Wang, J. (2019). Degradation of agricultural drainage water quantity and quality due to farmland expansion and water-saving operations in arid basins. Agricultural Water Management, 213, 185-192. https://doi. org/10.1016/j.agwat.2018.10.019.

Iakunin, M., Salgado, R., \& Potes, M. (2018). Breeze effects at a large artificial lake: Summer case study. Hydrology and Earth System Sciences, 22, 5191-5210. https://doi. org/10.5194/hess-22-5191-2018.

ICT (Institute of Earth Sciences) (2019). Atmospheric sciences water and climate. http://www.i-c-t.pt/g1/index. php/observations-and-forecast/ Accessed 2 January 2019.

Iglesias, A., Santillán, D., \& Garrote, L. (2018). On the barriers to adaption to less water under climate change: Policy choices in Mediterranean countries. Water Resources Management, 2018, 1-14. https://doi.org/10.1007/s11269-018-2043-0.

IPCC (Intergovernmental Panel on Climate Change) (2014). Climate change 2014 synthesis report, 133 pp. www.ipcc. ch/ Accessed 2 May 2018.

IPMA (Instituto Português do Mar e da Atmosfera Portuguese Institute of the Sea and Atmosphere) (2017). Boletim Climatológico Anual de Portugal Continental 2017. Instituto Português do Mar e da Atmosfera, IP. http://www.ipma.pt/resources. www/docs/im.publicacoes/edicoes.online/20180323 /cHAXzjMhUzLfdgCRJIKG/cli_20171201_20171231 pcl_aa_co_pt.pdf Accessed 12 May 2018.

IPMA (Instituto Português do Mar e da Atmosfera - Portuguese Institute for Sea and Atmosphere) (2018). Normais climatológicas 1981-2010 provisórias de Beja. Instituto Português do Mar e da Atmosfera, IP. https://www.ipma. pt/pt/oclima/normais.clima/1981-2010/002/ Accessed 12 May 2018.

IUSS Working Group WRB (2014). World reference base for soil resources 2014, Update 2015. Rome: World Soil Resources Report $\mathrm{N}^{\circ}$ 106, FAO. http://www.fao.org/3/a-i3794e.pdf Accessed 12 May 2018.

Jones, E., \& van Vliet, M. T. H. (2018). Drought impacts on river salinity in the southern US: Implications for water scarcity. Science of the Total Environment, 644, 844-853. https://doi. org/10.1016/j.scitotenv.2018.06.373.

Li, T., Li, S., Lian, C., Bush, R. T., \& Xiong, L. (2018). A comparative assessment of Australia's lower lakes water quality under extreme drought and post-drought conditions using multivariate statistical techniques. Journal of Cleaner Production, 190, 1-11. https://doi.org/10.1016/j. jclepro.2018.04.121.

Liu, C.-W., Lin, K.-H., Kuo, Y.-M. (2003) Application of factor analysis in the assessment of groundwater quality in a blackfoot disease area in Taiwan. Science of The Total Environment 313 (1-3):77-89

Lutz, S. R., Mallucci, S., Diamantini, E., Majone, B., Bellin, A., \& Merz, R. (2016). Hydroclimatic and water quality trends across three Mediterranean river basins. Science of the Total Environment, 571, 1392-1406. https://doi.org/10.1016/j. scitotenv.2016.07.102.

Machado, R. M. A., \& Serralheiro, R. P. (2017). Soil salinity: Effect on vegetable crop growth. Management practices to prevent and mitigate soil salinization. Horticulturae, 3(30), 1-13. https://doi.org/10.3390/horticulturae3020030.

Maas, E. V., \& Hoffman, G. J. (1977). Crop Salt ToleranceCurrent Assessment. Journal of the Irrigation and Drainage Division, 103(2), 115-134.

Merchán, D., Causapé, J., \& Abrahão, R. (2013). Impact of irrigation implementation on hydrology and water quality in a small agricultural basin in Spain. Hydrological Sciences Journal, 58(7), 1400-1413. https://doi.org/10.1080 /02626667.2013.829576.

Mil-Homens, M., Stevens, R. L., Cato, I., \& Abrantes, F. (2007). Regional geochemical baselines for Portuguese shelf sediments. Environmental Pollution, 148(2), 418-427. https:// doi.org/10.1016/j.envpol.2006.12.007

Mosley, L. M., Zammit, B., Leyden, E., Heneker, T. M., Hipsey, M. R., Skinner, D., \& Aldridge, K. T. (2012). The impact of extreme low flows on the water quality of the lower Murray River and lakes (South Australia). Water Resources Management, 26, 3923-3946. https://doi.org/10.1007 /s11269-012-0113-2.

Mosley, L. M. (2015). Drought impacts on the water quality of freshwater systems; review and integration. Earth-Science Reviews, 140, 203-214. https://doi.org/10.1016/j. earscirev.2014.11.010.

Morais, M. M., Serafim, A. M., Pinto, P., Ilhéu, A., \& Ruivo, M. (2007). Monitoring the water quality in Alqueva reservoir, Guadiana River, southern Portugal. In G. Gunter \& M. Carmo (Eds.), The 12nd international specialized conference on watershed \& river basin management (pp. 96-112). Germany: Technical University of Berlin.

Muangthong, S., \& Shrestha, S. (2015). Assessment of surface water quality using multivariate statistical techniques: Case study of the Nampong River and Songkhram River, Thailand. Environmental Monitoring and Assessment, 187, 548. https://doi.org/10.1007/s10661-015-4774-1.

Oster, J. D., \& Schroer, F. W. (1979). Infiltration as influenced by irrigation water quality. Soil Science Society of America Journal, 43, 444- 447.

Palma, P., Alvarenga, P., Palma, V., Fernandes, R. M., Soares, A. M. V. M., \& Barbosa, I. R. (2010). Assessment of anthropogenic sources of water pollution using multivariate statistical techniques: A case study of the Alqueva's reservoir, Portugal. Environmental Monitoring and Assessment, 165, 539-552. https://doi.org/10.1007/s10661-009-0965-y.

Palma, P., Ledo, L., Soares, S., Barbosa, I. R., \& Alvarenga, P. (2014a). Spatial and temporal variability of the water and sediments quality in the Alqueva reservoir (Guadiana Basin; southern Portugal). Science of the Total Environment, 470 $471,780-790$. https://doi.org/10.1016/j. scitotenv.2013.10.035.

Palma, P., Köck-Schulmeyer, M., Alvarenga, P., Ledo, L., Barbosa, I. R., López de Alda, M., \& Barceló, D. (2014b). 
Risk assessment of pesticides detected in surface water of the Alqueva reservoir (Guadiana basin, southern of Portugal). Science of the Total Environment, 488-489, 208-219. https://doi.org/10.1016/j.scitotenv.2014.04.088.

Palma, P., Ledo, L., \& Alvarenga, P. (2015). Assessment of trace element pollution and its environmental risk to freshwater sediments influenced by anthropogenic contributions: The case study of Alqueva reservoir (Guadiana Basin). Catena, 128, 174-184. https://doi.org/10.1016/j.catena.2015.02.002.

Palmer, W.C. (1965). Meteorological drought. Res. Paper no. 45, Washington, D.C.: Weather bureau.

Paranychianakis, N. V., \& Chartzoulakis, K. S. (2005). Irrigation of Mediterranean crops with saline water: From physiology to management practices. Agriculture, Ecosystems \& Environment, 106, 171-187. https://doi.org/10.1016/j. agee.2004.10.006.

Potes, M., Salgado, R., Costa, M. J., Morais, M., Bortoli, D., Kostadinov, I., \& Mammarella, I. (2017). Lake-atmosphere interactions at Alqueva reservoir: A case study in the summer of 2014 (p. 691). Tellus A: Dynamic Meteorology and Oceanography. https://doi.org/10.1080 /16000870.2016.1272787.

Rengasamy, P. (2010). Soil processes affecting crop production in salt-affected soils. Functional Plant Biology, 37, 613-620. https://doi.org/10.1071/FP09249.

Rhoades, J.D. (1977). Potential for using saline agricultural drainage waters for irrigation. Free. Proc. water Management for Irrigation and Drainage. ASCE. Reno, Nevada. 20-22 July 1977, pp 85-116.

Rhoades, J. D., Kandiah, A., \& Mashali, A. M. (1992). The use of saline waters for crop production. In FAO irrigation and drainage paper 48. Rome: Food and Agriculture Organization of the United Nations.

Scanlon, B., Jolly, I., Sophocleous, M., \& Zhang, L. (2007). Global impacts of conversions from natural to agricultural ecosystems on water resources: Quantity versus quality. Water Resources Research, 43, 1-18. https://doi. org/10.1029/2006WR005486.

Serafim, A., Morais, M., Guilherme, P., Sarmento, P., Ruivo, M., \& Magriço, A. (2006). Spatial and temporal heterogeneity in the Alqueva reservoir, Guadiana River, Portugal. Limnetica, 25(3), 161-176.

Shrestha, S., \& Kazama, F. (2007). Assessment of surface water quality using multivariate statistical techniques: A case study of the Fuji river basin, Japan. Environmental Modelling \& Software, 22, 464-475. https://doi.org/10.1016/j. envsoft.2006.02.001.

Simeonov, V., Stratis, J. A., Samara, C., Zachariadis, G., Voutsa, D., \& Anthemidis, A. (2003). Assessment of surface water quality in northern Greece. Water Research, 37(17), 41194124.

StatSoft, Inc. (2004). STATISTICA (data analysis software system), version 7. https://www.tibco.com/products/tibcostatistica
Tanji, K. K., \& Kielen, N. C. (2002). Agricultural drainage water management in arid and semi-arid areas. In FAO irrigation and drainage paper 61. Rome: Food and Agriculture Organization of the United Nations.

Tomaz, A., Patanita, M., Guerreiro, I., Dôres, J., Boteta, L., \& Ferro Palma, J. (2018). Efficient use of water and nutrients in irrigated cropping systems in the Alqueva region. Spanish Journal of Soil Science, 8(1), 12-23. https://doi.org/10.3232 /SJSS.2018.V8.N1.02 .

U.S. Salinity Laboratory Staff. (1954). Diagnosis and improvement of saline and alkali soils. Handbook no. 60. Washington, DC: US Department of Agriculture.

Valverde, P., Serralheiro, R., Carvalho, M., Maia, R., Oliveira, B., \& Ramos, V. (2015). Climate change impacts on irrigated agriculture in the Guadiana river basin (Portugal). Agricultural Water Management, 152, 17-30. https://doi. org/10.1016/j.agwat.2014.12.012.

van Vliet, M. T. H., \& Zwolsman, J. J. G. (2008). Impact of summer droughts on the water quality of the Meuse river. Journal of Hydrology, 353, 1-17. https://doi.org/10.1016/j. jhydrol.2008.01.001.

Vicente-Serrano, S. M., Lopez-Moreno, J., Beguería, S., LorenzoLacruz, J., Sanchez-Lorenzo, A., García-Ruiz, J. M., AzorinMolina, C., Morán-Tejeda, E., Revuelto, J., Trigo, R., Coelho, F., \& Espejo, F. (2014). Evidence of increasing drought severity caused by temperature rise in southern Europe. Environmental Research Letters, 9, 44001, 9 pp. https://doi.org/10.1088/1748-9326/9/4/044001.

Ward Jr., J. H. (1963). Hierarchical grouping to optimize an objective function. Journal of the American Statistical Association, 58, 236-244.

Weil, R. R., \& Brady, N. C. (2016). The nature and properties of soils (fifteenth ed.). Columbus: Pearson.

Wilcox, L. V. (1955). Classification and use of irrigation waters, circular no. 969. Washington, D.C.: United States Department of Agriculture.

Williams, W. D. (1999). Salinisation: A major threat to water resources in the arid and semi-arid regions of the world. Lakes \& Reservoirs: Research and Management, 4, 85-91.

Yang, J., Strokal, M., Kroeze, C., Wang, M., Wang, J., Wu, Y., Bai, Z., \& Ma, L. (2019). Nutrient losses to surface waters in Hai he basin: A case study of Guanting reservoir and Baiyangdian lake. Agricultural Water Management, 213, 62-75. https://doi.org/10.1016/j.agwat.2018.09.022.

Zalidis, G., Stamatiadis, S., Takavakoglou, V., Eskridge, K., \& Misopolinos, N. (2002). Impacts of agricultural practices on soil and water quality in the Mediterranean region and proposed assessment methodology. Agriculture, Ecosystems \& Environment, 88, 137-146.

Publisher's note Springer Nature remains neutral with regard to jurisdictional claims in published maps and institutional affiliations. 